\title{
Business planning and management accounting in strategic networks: theoretical development and empirical evidence from enterprises' network "agreement"
}

\author{
Andrea Cardoni*
}

Received: 18 January 2012

Accepted: 29 October 2012

\begin{abstract}
This paper aims to explore the nature, the role and the main features of business planning and management accounting processes in strategic networks, with particular reference to alliances formalized through the network "agreement" recently defined by the Italian government with law n. 122/2010. Despite the theoretical importance of the issues above mentioned, there has been little empirical research specifically related to these topics. In addition no theoretical and empirical research is still available to evaluate the managerial and accounting implications of the new legal framework established by the Italian government. After having defined the theoretical and institutional framework, this study performs a comparative case study on fifty network "agreements" formalized under the new law, with the purpose of exploring the theoretical and practical implications of an emerging phenomenon in its preliminary stage.
\end{abstract}

Keywords: strategic networks, business planning, management accounting, network “agreement” (law n. 122/2010)

\section{Introduction}

In the information age, firms are increasingly organizing their activities through networks (Castells, 2000). The Business environment is seen more like a "rain forest" than a "jungle" (Hakansson et al., 2009) so that new paradigms are emerging in management (Bastia, 1984; Jarrillo, 1988; Lai, 1991, Mancini, 1999; Garzella, 2000; Antonelli, 2001) and accounting literature (Otley et. al, 1995; Hopwood, 1996; Tomkins, 2001).

\footnotetext{
*Università degli Studi di Perugia, e-mail: acardoni@unipg.it.
} 
In many countries several institutions have encouraged the implementation of strategic alliances to stimulate the national and regional development (Etzkovitz, 2008; Johanson et al., 2010). The last initiative of the Italian government is based on the definition of a new legal framework (article 42 of law n. 122/2010) to formalize the implementation of cooperation strategy: the enterprises' network “agreement” (Cafaggi, 2009), hereafter the "agreement". This is a contract which allows companies and entrepreneurs to cooperate in the fields of their activities in order to increase their innovation capacity and competitiveness.

The concept of network emerging from this framework could be interpreted as consistent with the management literature focusing on "strategic network" (Jarillo, 1988; Gulati, 2007), considered as an intentional, longterm alliance enabling different companies to acquire or defend the competitive advantage against competitors outside the network.

Despite the importance of collaborative strategic networks and their business planning and accounting processes, there has been little empirical research specifically related to these topics. These studies are often focused on a single case-study (Caglio et al., 2008), hence denying the possibility to compare the different managerial behaviors applied to implement collaborative strategies. In addition theoretical and empirical researches are not yet available to evaluate the managerial and accounting implications on the new legal framework established by the Italian government with law n. 122/2010.

The purpose of this study is to gain access to and insight from real cases of networks formalized according to the mentioned "agreements". This will help us understand some critical aspects related to the network strategic planning and management accounting on an empirical basis. In particular, the following two research questions were used to guide this investigation.

Research Question 1: What is the strategic context and the business planning framework in enterprises' networks formalized through the “agreement” defined by law n.122/2010?

Research Question 2: What kind of management accounting techniques and procedures are identified on the "agreement" to support the collaborative strategy and operations and what is the role assigned to them?

In order to examine the selected issues on an empirical basis, after drawing a theoretical and institutional framework, the study adopts a comparative case-study design, performing a qualitative content analysis of the first fifty "agreements" signed up until June 2011. As the study focuses on 
emerging issues related to a very recent legislative framework, the nature of the research is exploratory and the main purpose is to understand a phenomenon in its preliminary stage.

The aim of the paper is therefore to break ground and set the stage for future research in the area of planning and management accounting for strategic networks, with particular reference to strategic alliances formalized under the framework of law n. 122/2010. The study is also meant to better inform network managers, practitioners and policy makers about the "state of the art" of the implemented "agreements" after a little more then one year from the introduction of the law 122/2010. The intent is to encourage a dialogue and possible partnership between university, government, business networks and practitioners in order to provide assistance for the improvement of the legal framework and the implementation of strategic networks.

\section{Investigating and supporting strategic networks: new paradigms and evolving istitutional framework}

The subject of the strategic analysis and management accounting of networks has come to the attention of academics and practitioners for the last decades (Bastia, 1984; Jarrillo, 1988; Lai, 1991; Otley, 1995; Hopwood, 1996; Mancini, 1999; Garzella, 2000; Antonelli, 2001; Tomkins, 2001; Ricciardi, 2003; Hakansson et al., 2009) in a broader framework of theoretical developments.

The emergence of the global knowledge economy (Mokyr, 2002; Vitro, 2005; Huggins, 2008) is creating innovative systems and models of work, having a deep impact on business environment and organizational interdependecies. To define the current business landscape, some authors (Hakansson et al., 2009) suggest the metaphor of the "rainforest", indicating that one of its basic feature is the intricate interdependency among companies that requires an alternative framework to be studied.

\subsection{Different perspectives on networks literature and interorganiza- tional accounting}

A network can be defined as "a set of business entities, legally independent, reciprocally committed to implement a deliberate and finalised cooperation strategy, leveraging the technical and economical complemen- 
taries in achieving joint economic objectives, which indirectly benefit the individual businesses” (Bastia, 1984, p. 65).

Within economics there have been several approaches to the study of networks and alliances, mainly including transaction cost economics, strategic management and institutional perspective.

Transaction cost economists (Williamson, 1975) have argued that networks are hybrid forms of organization between markets and hierarchy and that they occur when transaction costs associated with a specific exchange are too high for an arm's length market exchange but not high enough to mandate vertical integration (Hennart, 1988). In transaction cost economic literature various roles have been indentified for management accounting in inter-firm settings that relates to specific accounting techniques and different uses of accounting information. These roles include the use of financial and non-financial information in the "make or buy or ally" decisions, in the selection of a potential partner, during the management of cooperation and in the monitoring and evaluation of collaborations activities (Seal et al. 1999; Caglio et al., 2008; Anderson et al., 2009). These studies often examined inter-firm accounting in conjunction with the issue of motivation and incentives, underscoring the importance of studying accounting in a broader control context (Anderson et al., 2010).

Strategic management literature recognises business relationships as another type of resource that a company can use in the strategic game. The opportunity to mobilize others as "partners" has increasingly become an emergent issue in the strategic management literature. From a resourcebased perspective the importance of business relationship is emphasized by the idea that a firm's critical resources may span the boundaries of the firms itself and be embedded in inter-firm resources and routines (Dyer et al. 1998). Similarly, Sanchez et al. (1997) argue that the resources that a firm uses reside both within the firm (firm-specific resources) and in other organizations (firm-addreassable resources). Also Gulati (2007) claims that a firm's network of business partners should be considered as an inimitable resource itself and as a means by which to assess others' inimitabile resources. In this stream of research two concepts clearly emerge: on the one hand, the "strategic alliances", defined as "any voluntary and enduring arrangements between two or more firms involving the exchange, sharing, or codevelopment of products, tecnologies, or services” (Gulati, 2007; p. 1) and on the other hand the "strategic network" as "long-term, purposeful arrangements among distinct but related for profit organizations that allow those companies in them to gain or sustain competitive advantage vis-à-vis their competitors outside the networks" (Jarillo, 1988; p. 32). 
In studies influenced by institutional theory, collaborations and networks encompass a broad range of inter-organizational relationships (Scapens et al., 2010). Some authors (Philips et al., 2000) argued that institutions supply the rules and resources upon which collaboration is build. Thus, to fully understand and explore the dynamics of collaboration and networks, it is crucial to examine the instituitionalised patterns of rules and routines, emphasizing the objective and the external aspects of the instituitional environment (Sharfman et al., 1991). In this perspective, cost management and other accounting routines could become part of the broader institutional context (Coad et al., 2006) which helps to give order to the complexity created by the institutional pressures that influence nature and character of inter-organizational relationships. In the work of Greenwood et al. (2002), Parkhe (2003), and Burns et al., (2000), the research explores the evolutionary process through which management accounting and control practice develop, considering the interaction between micro and meso institutions within the organisation and the broader macro and meta institutions of the instituitional field in which the relationship is set. According to Parkhe (2003) it is important to recognise the meta and macro institutions when studying inter-organisational relationships in different countries: economies with different socio-legal systems are likely to have substantial different approaches to accounting for inter-organisational relationships - influenced in large part by their institutional environments.

It is widely recognised that a critical factor influencing the implementation of collaborative strategies is the policy makers orientation: the creation and development of networks is indicated as the right strategy needed to adapt the business structure to the main features of the knowledge economy, especially in the economic contexts characterized by the presence of SMEs (Donkels et al., 1995; Macpherson et al., 2007) and entrepreneurial businesses (Parker, 2008). Based on the valuble benefits generated in terms of learning, the development of entrepreneurial processes (Elfring et al., 2003), innovation and competitive advantage (Cooke, 1996; Littunen, 2000; Rogers, 2002), value creation (Holm et al., 1999), growth and survival (Havnes et al., 2001; Bosma et al., 2004), network strategy is seen as the route to stimulate business development and economic growth at international, national and regional levels (Etzkovitz, 2008; Johnson et al., 2011; Pavit, 2004).

Adopting a comparative international perspective on regional supporting programmes some authors (Johanson et al., 2011) argued that succesful networking development is characterized by an engineered process. This process is started by a trigger entity (goverment agencies, consultants, specific companies, entrepreunerial individuals, banks, universities, other ac- 
tors) that actively strives to create some sort of cooperation among a group of actors (Doz et al., 2000) as it is able to plan and develop interdependecies and create interactions and cooperations that are difficult for the actors themselves to recognise. The opposite of an engineered process is an emergent one, in which no intervention by a trigger entity is required and the member selection is self-regulated.

According to this framework, strategic networks are the result of an enginereed process, where the working arrangements are specified in written contracts and fulfilled in a formal organization, goals are planned and specified in a predetermined time horizon, the cooperation is based on "network capital" rooted in a business and economic rationality and focused on investing in relationships as a means to increase business performances (Huggins, 2010).

In order to understand the key features of strategic networks, a growing need has emerged to investigate in more details the concepts of strategic planning and management accounting for collaborative organizations. Exploiting complementary skills and resources, identifying particular threat and taking advantage of a particular opportunity require a business planning process (Rullani, 2001; Ricciardi, 2003) which, although complex in construction (Kukalis et al., 1995), has the general characteristics of business planning as developed by the existing literature.

A comprehensive literature review in the field of strategic planning (Ghezzi et al. 2010) helps us to understand that the main issues to be taken into consideration in the present study are the following:

- strategic planning as formal versus informal process (Micklethwait et al., 1997; Mintzberg, 1994);

- balance of internal and external planning focus (Ansoff, 1985; Andrews 1987; Porter 1991; Houben et al., 1999; Ferrel et al., 1998; Bracker et al., 1986, Boyton et al., 1984; Porter, 1980);

- clear statement of strategic goals and objectives, where the former are defined as "broad business results that a business is absolutely committed to attaining stated in terms of general intentions" while the latter are "specific step which enables a business to accomplish a goal" presenting the following characteristics: result-driven and not activity-driven; specific; measurable; attainable; time-related (IFAC, 2006);

- balance of market-driven and process-driven approaches in defining the action plan: some authors (Bonn, 1996) suggest - to avoid the risk of misaligning delivered and expected performances - to balance 'marketdriven' perspective (focused on customer's needs) with a 'technology- 
driven' approach (focused on internal technology and actual product portfolio).

The issue of performance measurement and representation of strategic networks can benefit from the new paradigms emerged in management and accounting literature from the mid-1990s, when many important scholars (Otley et al., 1995; Hopwood, 1996; Shields, 1997) emphasized the importance of extending the domain of accounting across the traditional boundaries and called for a need to encourage the research accounting in interorganisational settings.

In this evolutionary perspective, Italian literature has traditionally accorded much importance to the study of accounting issues for networks. Consistent with a solid tradition, this subject is considered to be central for the understanding of the new organizational structures and needs to be investigated in close connection with the management issues (Riparbelli, 1962; Azzini, 1964). Even more "the gap between the evolution of managerial and organizational structures and the definition of adequate information systems can influence the development of more effective forms of networking, as the support of managerial and organizational processes is not considered a crucial role of information” (Lai, 1991, p. 119). Given this framework, Bastia (1984) devotes a significant part of his work illustrating the impact of inter-firm relations on capital and income structures (introducing the concept of "combined financial statement"), on transfer pricing definition, on productivity and cost measurement. By broadening the analysis perspective, Mancini (1999) focuses on the issues of "relational control" and more recently $(2010,2011)$ illustrates an integrated scheme "information-governance-control-performance" where "the differentiating factor of information sharing - together with the information system which it originates from - are the main components on which a company can implement an effective governance and control of its alliances" (2011, p. 75).

Inside these different streams international and national literature demonstrates that a broad range of special accounting techniques, methods and control mechanisms have been developed with the purpose of handling accounting problems related to business relationships: openbook accounting, target costing, value chain accounting, quality plans, programmes of innovations, alliance boards, joint task groups, tournament procedures, supplier certifications, non-financial measures and riskrewards schemes (Mouritsen et al., 2001; Langfield-Smith et al., 2003; Dekker, 2003; Dekker, 2004; Seal et al., 1999) and the specific application of balanced scorecard (Kaplan et al., 2010). These methods influence 
the motivation and incentives of strategic partners and should be analysed in the broader institutional context.

\subsection{Institutional support to network formation: the case of legal framework defined by law no. 122/2010}

In many countries several institutions have encouraged the implementation of strategic alliances to stimulate the national and regional development, providing financial support to companies willing to cooperate and set up a network. These measures tend to define an institutional framework able to influence the process of network formation and the role of accounting on interorganizational settings.

Among European countries, the recent inititive undertaken by the Italian governement represents the first case of a comprehensive approach implemented to this purpose, by defining a new legal framework (law n. 122/2010) to formalize the alliances (the enterprises' network "agreement") (Cafaggi, 2009) and providing a scheme of tax incentives. In a generalizable perspective the Italian case allows thus to understand how the strategic networks are formed and work, and the extent to which they can be influenced by the institutional context.

According to law n.122/2010 the contract is the legal tool needed to formalise strategic alliances among entrpreneurs whose "aim is to enhance, on a individual or collective basis, their innovation capabilities and their competitiveness on the market" undertaking the commitment to: i) "cooperate in different ways on a specific business related to the management of their own enterprises (or); ii) sharing information and services of an industrial, commercial, technical or technological kind (or); ii) managing in a collaborative way one or more activities included in the mission statement of the companies".

From an organizational perspective the contract can be implemented for a wide variety of collaborations, both in terms of vertical alliance - in the form of supply chain among companies that operate in the same sector at different stages of production, and horizontal alliance - with competitors sharing some special projects of innovation and strategic development. The last strategic option can be useful especially for SMEs that, though competing in their local markets, may form special alliances to reach wider markets or implement internationalization project.

However, even on the structural perspective, the contract does not provide size limits and can be signed by SME's or large companies and be util- 
ized to set up collaboration among partners with homogeneous or heterogeneous dimensions.

The support measure consists in a tax deferral through which a part of taxable revenue - targeted by participating companies for achievieng the purpose of the contract and put in a specific reserve - will be excluded from the calculation of taxable income, for the duration of the contract. Such benefit is temporary, given that the money put aside for the partecipation to the network will be included in the tax base once the contract is fulfilled.

The contract has to be drawn according to a formal procedure with a notary, requiring an official registration with the competent Chamber of Commerce where the companies reside, and it must indicate (law n. 122/2010): i) references of partners; ii) strategic objectives; iii) performance measurement criteria to assess the progress towards the achievement of strategic goals; iv) network action plan; v) duration of the agreement; v) specific endowment to manage cooperation activity.

Assessing this regulatory discipline in the light of the theoretical framework, the kind of collaborative strategy defined by law n. 122/2010 is consistent with the concept suggested by strategic management literature focusing on "strategic network" (Jarillo, 1988; Gulati, 2007), considered as an intentional, long-term alliance enabling different companies to acquire or defend the competitive advantage against competitors outside the network. The requirement of the explicit elaboration of the "strategic objectives" and the "network action plan" implies an engineered process of network set-up and emphasizes the role of a formalized strategic planning process, ensuring higher level of efficiency and stability (Ricciardi, 2003) ${ }^{1}$. On the other hand, the adoption of "agreements" to formalize networks and strategic alliances, can entail lower levels of trust and control (Das et al., 1998) and a risk of maintaining too much flexibility (Das et al, 1999; Mahama, 2006) with a negative impact on goal setting and performance control.

Even if no mandatory rules are established by law n. 122/2010 with reference to management accounting tools or financial reports, the need to indicate the shared performance measurement criteria to assess the fulfillment of strategic obejectives raises important issues on management control and accounting techniques for internal and external needs.

1 "When the network is the result of planning it has higher levels of stability. Conversely, if the partners do not feel the opportunity and the need to join a strategic network project, the structure is weak in terms of efficiency and stability” (Ricciardi, 2003, p. 180). 


\section{Exploring strategic networks: in search of evidences from a multi- ple cases analysis}

The methodological approach adopted in this study is broadly qualitative, although some elements of quantitative research are employed where appropriate. Given the complexity and the social dimension of interorganizational relationships our ontological position is based on the idea that social phenomena and their meaning are produced through social interaction and are in a constant state of revision (Strauss, 1987). This position also suggests that the categories employed to understand the natural and social world are in fact social products and their meaning is constructed in through an interaction (Potter, 1996). In terms of epistemological orientation, our study considers the reality of collaborative networks as a phenomenological issue, in a background where the individuals make sense of the world (Schulz, 1962).

Considering that our research on network "agreement" poses 'what' questions, has no control over behavioural events and is focused on a contemporary phenomenon, the most appropriate study methodology is an exploratory case study (Yin, 2004), defined as "an empirical inquiry that investigates a contemporary phenomenon within its real-life context" (Yin, 1984) seeking to understand a problem that needs to be clearly defined.

We determine to use a multiple cases approach in order to strenghten the empirical findings and make interpretations more robust (Yin, 2004). This approach embodies the logic of comparison implying that we can better understand social phenomena when they are compared in relation to two or more meaningfully contrasting cases or situations. Conceptually, analysing a significant sample of real cases of network "agreement" allows for direct replication of future research.

The entire population is represented by all network "agreements" signed under the new legislation framework defined by the Italian government with law n. 122/2010. In december 2011 this population includes 200 "agreements" recorded in the official Chamber of Commerce registers, at provincial and national level (Unioncamere). Given the exploratory nature of the research the selection used in this study is the purposeful sampling of the first fifty signed contracts implemented and registred in the Chamber of Commerce until June 2011. The dimensions characterizing the population and the sample are the follow (Table 1). 
Tab. 1 - Population and sample of network "agreements"

\begin{tabular}{lcccc}
\hline & \multicolumn{2}{c}{ Population } & \multicolumn{2}{c}{ Sample } \\
\hline & $\mathrm{N}$. & $\%$ & $\mathrm{~N}$. & $\%$ \\
\hline - "Enterprises network agreements" & 200 & & 50 & \\
Involving: & & & & \\
- Regions & 19 & & 16 & \\
- Provinces & 84 & & 56 & \\
- Business entities & 968 & $100,0 \%$ & 291 & $100,0 \%$ \\
of which: & & & & \\
- limited companies & 686 & $70,8 \%$ & 221 & $75,9 \%$ \\
- partnership & 129 & $13,3 \%$ & 29 & $10,0 \%$ \\
- individual business & 105 & $10,8 \%$ & 23 & $7,9 \%$ \\
- mutual entities & 33 & $3,4 \%$ & 11 & $3,8 \%$ \\
- foundations & 2 & $0,2 \%$ & 2 & $0,7 \%$ \\
- others & 15 & $1,5 \%$ & 7 & $2,4 \%$ \\
\hline
\end{tabular}

Source: Chamber of Commerce - Unioncamere

In some contracts the alliances are formalised to implement a supply chain, often led by a medium-large company, but in most cases they include SMEs operating in the same sector, holding complementary skills and specializations and interested in developing projects, products or markets by exploiting the potential synergies among them.

After having defined the sample, we obtained from the Chamber of Commerce the full text of the contract and related documents (i.e. network business plan, network regulation, etc., when available in the official registers) of the enterprises' network agreements, using this documentation as primary source of analysis. In a methodological perspective (Bryman, 2008) documents are intendeed as materials that: i) can be read; ii) have not been produced specifically for the purpose of social research; iii) are preserved so that they become available for further analysis; iv) are relevant to the concern of social researchers. Because the contracts have not been created specifically for the purpose of the research, the possibility of reactive effect can be largely discounted as a limitation on the validity of the data (Bryman, 2008).

The network "agreement" could be classified as an official company document deriving from private source that can certainly be seen as authentic, credible and meaningful, being implemented under a formal procedure (Scott, 1990). Due to official or quasi-official character of such materials the question of represetitiveness requires some greater consideration and a caution in attempting to treat them as depictions of reality. On this point, Atkinson et al. (2004) demonstrate that documents should be viewed as a distinct level of "reality" in their own right, arguing that they are significant for what they were supposed to accomplish and who they are written for. As the "agreements" are documents that can be read by others and have to fulfill legal requirements they are likely to be written with a particolar perspective so that we are aware that they can contain some bias. 
In order to analyse the selected sample of agreements in a comprehensive way, we adopted a comparative design, and studied the contrasting cases using an identical method. Particularly we used the approach of qualitative content analysis that comprises a searching-out of underlying themes in the materials analysed, following the specific approach of "ethnographic content analysis" (Altheide, 1996).

After generating the research questions, we have understood the theoretical and legal context in which the documents are generated through the literature review and the study of law n. 122/2010. Then we proceeded to analyse a small number of contracts in order to define the most appropriate method to collect and interpret the information. Finally we define the categories and the scheduling for the data collection in correlation with the research questions (Table 2).

\section{Tab. 2 - Research questions, categories and scheduling for data collection}

\begin{tabular}{|l|l|}
\hline \multicolumn{1}{|c|}{ Research questions } & \multicolumn{1}{|c|}{ Categories and scheduling } \\
\hline $\begin{array}{l}\text { 1) What is the strategic context } \\
\text { and the business planning } \\
\text { framework in enterprises' net- } \\
\text { works formalized through the } \\
\text { "agreement" defined by law } \\
\text { n.122/2010? }\end{array}$ & $\begin{array}{l}\text { 1.a. Strategic context: the analysis observes the possible presence } \\
\text { of ale) and the eventual reference to an "engineered process" (ex- } \\
\text { plicit reference to a strategic networking model that inspires the } \\
\text { collaboration); } \\
\text { 1.b. Strategic analysis: the research explores if the contracts report } \\
\text { some internal and/or external strategic analysis to support the goal- } \\
\text { setting of the network; } \\
\text { 1.c. Strategic objectives: the study seeks to understand the features } \\
\text { of the goal-setting process, evaluating if it is general (strategic } \\
\text { goals) and/or specific (strategic objectives); } \\
\text { 1.d. - Strategic action plan: we refer to the main strategic actions } \\
\text { indicated in the contract, evaluating if they present a market-driven } \\
\text { and/or process-driven approach. }\end{array}$ \\
\hline $\begin{array}{l}\text { 2) What kind of management } \\
\text { accounting techniques and pro- } \\
\text { cedures are identified on the } \\
\text { "agreement" to support the } \\
\text { collaborative strategy and op- } \\
\text { eration and what is the role as- } \\
\text { signed to them? }\end{array}$ & $\begin{array}{l}\text { 2.a. - Strategic performance measurement: the analysis focuses on } \\
\text { the measurement criteria for the strategic results formalized in the } \\
\text { contract, evaluating if the partners commitment refers to a general } \\
\text { and/or specific indicators and reports; } \\
\text { 2.b. - Management accounting techniques and procedures: the } \\
\text { study observes if some tools/processes of management accounting } \\
\text { are defined to support the network control and/or the cost- } \\
\text { ing/pricing information; } \\
\text { 2.c. - Financial budgeting and reporting: we investigate if the con- } \\
\text { tracts require to elaborate financial budget and/or report to meet } \\
\text { internal or external needs; } \\
\text { 2.d. - Role of accounting techniques and procedures: following the } \\
\text { above mentioned analysis, we provide an overall evaluation about } \\
\text { the role assigned from the partners to the management accounting } \\
\text { and performance measurement techniques. }\end{array}$ \\
\hline
\end{tabular}


In the light of the research design and method adopted, the study performed is characterised by the following limitations:

- the contract may not be complete or to use a formal languange with consequent difficult meaning to interpret in a strategic business perspective;

- the reasons of confidentiality could have led to the partners of the network to use generic statements not to reveal strategic information;

- if the partners have performed a business planning process, the specific context in which the documentation is processed can lead partners not to connect the strategic outcomes with the clauses formalized on the "agreement";

- the first contracts may be influenced by the very recent introduction of the new legal framework;

- some agreements may be biased by fiscal incentives and alliances established only with the scope to benefit from tax deferrals.

The delimitations of our investigation are outlined below:

- this study only includes the first fifty network "agreements” signed until June 2011;

- of abovementioned contracts, we have analysed only the text and the annexed documentation, not considering other information like sector, size, performance, etc. related to the partners and/or the network entities.

These delimitations allowed us to make the comparative case study manageable for data collection and find their reason on the exploratory nature of research. By the very nature of interpretative approach, our position has an effect on the research effort and we may have certain biases about network "agreements" and their content analysis and interpretation. To address any biases that could be cause to question the validity of this study, we have defined the specific categories analysed and collected the data applying the scheduling above illustrated.

\section{Weak strategic approach and traditional role of accounting on network implementation}

Applying the schedule on the selected network "agreements", with reference to strategic context and business planning framework we obtain the results illustrated on appendix A.

From the table it is possible to notice the small presence of trigger entities (26\%) and the limited reference to an engineered process of setting up and organization (32\%). If some elements of strategic analysis are reported, 
in most cases the reasons motivating the opportunity to form an alliance are based on internal (58\%) rather than external (20\%) factors. The goal-setting process often remains at a level of strategic goals definition (76\%), where the expected results are stated in terms of very general intention of competitiveness and innovation improvement. Only few agreements (26\%) elaborate strategic objectives trying to identify the specific targets the network wants to accomplish in terms of projects, line of business and production, market share or strategic synergies among partners. With reference to the action plan, the study shows a large number of agreements focused on network internal processes (86\%) emphasizing the need to implement the integration through the definition of common rules and regulations, the appointment of a single entity of certification, shared participation in exhibitions and markets, the organization of technical meetings and seminars and the registration of a common brand. In a small percentage of networks analysed (28\%) the strategic plan benefits from a clearer vision of the market opportunities and indicates the necessary actions to create value for a targeted group of customers.

In conclusion, the strategic context of the selected agereements is characterised by an "emergent" rather than "engineered" process with a negative impacts on the quality of business planning which tends to be less structured when there is not a "triggers entity" or the reference to an inspiring model of business interaction. The elements of business planning framework, even the mandatory ones ("strategic objectives" and "network action plans”) present on average a poor level of elaboration, containing general intentions and planned actions directed mainly on the internal processes and resources, without a clear vision of desired strategic positioning. Considering the institutional framework in which the agreement has been introduced, the above characteristics can be related to those networks that have been implemented mainly to exploit the tax benefits and the external incentives, without elaborating an effective business planning process.

However, there are important cases demostrating the significant link between "agreement" and strategic planning process. In the first case (Example \# 1), the contracts show that the business plan is considered as a central management procedure to support the collaborative strategy and the exploitation of synergies.

Ex. \# 1: "In order to implement the defined network strategies and operations and exploit the potential synergies among the enterprises, the partners approve on a regularly basis the business plan that identifies the financial commitment for each one". 
Other cases are representative of a clear definition of strategic goals (Example \# 2), strategic objectives (Example \# 3) and a coherent correlation between target setting and performance measurement (Example \# 4).

Ex. \# 2: "The strategic objective of the network is to find new business opportunities through Italian fashion brands (...), providing flexibile standard of production, quality control, short times of development and delivery, low prices, $100 \%$ italian made and related services of modelling and prototipation"

Ex. \# 3:”The strategic objectives are the following: - business development in Italy: 1. first year: obtaining at least one customer qualification and initiating the necessary commercial actions; 2. second year: reaching a minimum of $700.000 €$ of new business opportunities ; 3. third year: reaching a minimum of $1.500 .000 €$ of new business opportunities; - international business development: 1. first year: implementing the appropriate market researches and understanding legal, tax and economic environment of the target Country; 2. second year: setting up a joint venture with a local partner for organizing the operational and commercial activities; 3. third year: reaching a minimum of $1.500 .000 €$ of new business opportunities”.

Ex. \# 4: The strategic objective of the network is to "realise a Virtual Power Plant (VPP) system obtained with micro-generation systems based on solid oxid fuel batteries. The objective is to start the roll-out and the initial test of VPP in the first semester 2012 and to commercialise one or more VPP by 2015. The network companies agree on measuring the strategic goals achievement through periodical reports illustrating the work in progress in terms of actual results, timing and costs compared to budget, and showing the market evolution and the network development”.

These cases demonstrate that the network “agreement”, despite being a legal tool elaborated in a formal setting, is strongly influenced by the quality of business planning. The officiality of the document and the mandatory nature of some specific elements require a good strategic planning outcome that can comunicate to external stakeholders a valuable project of collaboration in order to give value to the network and to the single enterprises involved, though respecting the appropriate level of confidentiality. Beyond the issues of formality and confidentiality, the results show that the problem seems not to reside on formal or informal business planning procedure (Bonn et al., 1996), but on the lack of strategic thinking, a weakness that the management literature considers even worst (Loizos, 1998).

With reference to performance measurement and management accounting, the results are reported on Annex B.

The low development of strategic planning is accompanied by a limited mention of performance measurement and management control procedures. 
In more than half of the cases analysed (52\%) the measurement criteria are generic and do not provide any specification in terms of processes and monitoring indicators. In other cases (48\%) the contracts established the measurement of progress towards the achievement of strategic goals through the following solutions: i) assigning to the Management Committee the responsibility to implement appropriate control processes and audit reports (Example \# 5); ii) selecting qualitative parameters of activity (Example \# 6); iii) adopting quantitative parameters considered representative of strategic network performance (Example \# 7).

Ex. \# 5: "Every six months the Audit Committee will prepare a report illustrating the progress toward the strategic targets set by the network action plan; the report will be published in the section of the website reserved for the partners".

Ex. \# 6: "The partners share the following terms to measure the progress towards strategic goals. Specifically: preliminary studies on products and solutions; prototyping; patenting of research results, national and international industrialization and development”.

Ex. \# 7: "In order to assess the progress toward the strategic objectives, partners agree that at the end of each financial year, the Management Committee (....) proceeds to analyse the turnover of products developed under this agreement in order to assess the effectiveness of the marketing and communication strategies adopted".

A moderate degree of diffusion (52\%) occurs with reference to the processes and tools dedicated to the planning and control of network activities. In some contracts, the implementation of a managerial control system or the definition of shared analysis criteria for managing the business opportunities are considered as one of the basic points of the action program (Example \# 8).

Ex. \# 8: “The network action program provides: (.....); the adoption of management control system and related implementation of programs and softwares; the use of a set of indicators for monitoring the manufacturing processes and supporting the core business"

The lower incidence (26\%) relates to the agreements containing some indication about accounting tools and/or procedures to be implemented for supporting cost analysis and price quotation. However, in some cases the cost accounting is adopted as a tool for measuring the network performance and regulating the inter-organitational business relationship (Example \# 9) or a general commitment to reporting and accounting is required to the partners in managing the network activities (Example \# 10). 
Ex. \# 9: "Progress towards the objectives will be measured by setting the targets cost of the line of production "alfa" (...) and periodically comparing the actual cost of production with these targets".

Ex. \# 10: "Partners are required to prepare statements, reports and every accounting supports could be necessary for the activities assigned to them in compliance with regulations and procedures established with the customer”.

The additional results analysed show that the accounting financial perspective is on average more present than the managerial one. Even though law n. 122/2010 does not provide any obligation of accounting bookkeeping or mandatory financial statement, almost $70 \%$ of the contracts assign to Management Committee the obligation to prepare an annual report and, to a less extent (54\%), also the task of elaborating a financial budget. A very frequent clause contained in the agreements analysed is the following (Example \# 11).

Ex. \# 11: The partners are required to approve: - "an annual report on the activity performed, to be prepared in accordance with the mandatory accounting principles established by the civil code for limited companies and to be presented by the Management Committee by the end of March each year with reference to the activity performed in the previous year; - a financial budget, which must be presented no later than October $30^{\text {th }}$ of each year and referred to the program of activity the Management Committee intends to implement during the next calendar year".

From accounting theoretical and empirical perspectives, this kind of provision raises many interpretative issues, framing into the traditional regulatory scheme of limited companies the reporting problems of complex and articulated entities as the strategic networks. In this context, the preparation of the annual report requires a framework (in terms of structures Balance Sheet/Income Statement, general principles, accounting standards) that needs the prior definition of the networking business model and the use of innovative forms of reporting that cannot be implemented with a similar setting.

These cases demonstrate that many contracts interpret the accounting problems using traditional schemes and assigning to accounting processes and tools a formal role, not suitable to support the articulated information and control needs that arise in the management of a strategic network. In this sense, the study shows that many networks still have not activated the process of accounting "hybridization” (Miller et al., 2008) that literature considers the necessary step to support the effective functioning of hybrid form of organizations. 


\section{Conclusions}

The paper reports the results of an exploratory research aimed at investigating the business planning and management accounting processes in strategic networks, with particular reference to alliances formalized through the network "agreement" established by Italian goverment with law n. 122/2010. After having defined the theoretical and institutional framework, we designed a comparative case-study and performed a qualitative content analysis of the first fifty "agreements" signed up until June 2011, obtaining the findings below.

The strategic context of the selected agreements is characterised by an "emergent" rather than "engineered" process (low presence of "trigger entity" and limited reference to networking inspiring model) with a negative impact on the quality of business planning. As a consequence, it tends to be less structured (weak strategic analysis, general goal-setting definition, action plan focused on internal factors only). The elements of business planning framework, even those made mandatory by law n. 122/2010 ("strategic objectives" and "network action plans") reveal on average a poor level of elaboration, containing general intentions and planned actions directed mainly on the internal processes and resources without a clear vision of desired strategic positioning.

The low development of strategic planning is accompanied by a limited adoption of performance measurement and management control procedures. In more than half of the cases analysed the measurement criteria are generic and do not provide any specification in terms of processes and monitoring indicators. A moderate degree of diffusion occurs with reference to the processes and tools dedicated to planning and control of network activities, while cost accounting or pricing definition procedures are present in a small proportion of "agreements". The financial accounting tools are on average more present than the managerial ones, even though the budgeting and reporting issues of a complex and articulated entity tend to be framed into the traditional regulatory scheme of limited companies, frustrating the need of accounting innovation for strategic networks.

Considering the institutional framework in which the agreement has been introduced, the above characteristics can be related to those networks that have been implemented mainly to exploit the tax benefits and the external incentives, without elaborating an effective business planning process and/or defining a coherent management accounting system.

These findings provide a number of theoretical implications. From the strategic management perspective the study demonstrates the importance of 
business planning and management accounting as fundamental processes needed to implement the concept of strategic networks, enabling the necessary awareness of the network "resources" (Gulati, 2007) and allowing the development of the alliance in the "network capital" (Huggins, 2010). In this direction we might even say that, in the wide and varied types of potential alliances and hybrid forms of organization, the presence and consistency of strategic thinking and management accounting could be considered as discriminating elements to assess whether an alliance is "strategic" or not. These implications are important also in the managerial studies focused on economic development, confirming the important role played by the trigger-entity and the engineered process in activating strategic networks. Indeed, considering the large number of SMEs involved in the network "agreements", the fact of leaving to spontaneous forces the business planning and management accounting tends to reproduce the weak competence these companies show in strategic analysis and managerial tools (Braker et al. 1986; Brinckmann, 2010).

Moving into the institutional perspective, the research shows the partial influence of institutional factors related to the legal framework defined by law n. 122/2010 which, although embedding the concept of strategic network, needs to be accompanied by a managerial, professional and cultural improvement specifically related to strategic and performance measurement in networks. From the accounting perspective, this analysis confirms the necessity of new paradigms and the need to investigate in more details the issues of the lateral process of information. The process of "hybridization" of organizational structures must be extended as soon as possible to the "hybridization" of accounting practices, processes and expertises (Miller et al., 2008) encouraging the close interaction between practice and theory (Hakansson et al., 2010) in order to stimulate the new forms of business development.

Given the exploratory nature of the study, the above findings open additional scenarios and indicate some possible directions for future research, such as:

- longitudinal case studies to investigate what the relationship between formal and informal managerial behaviour in strategic planning and management accounting is, with particolar reference to the network “agreements” pursuant to law n. 122/2010;

- quantitative analysis of the correlation between business planning/ management accounting settings and some critical variables such as: partner dimensions (micro, small, medium and large enterprises), business sectors, networking model, companies and network performances, etc. 
Besides the exploratory nature of our research, it is believed that the research holds some interesting managerial and public policy implications as well. First of all, the business planning framework elaborated to analyse the "agreement" can guide managers in defining the network settings, indicating what is the best strategic context and the main dimensions to consider when elaborating a consistent business plan. Furthermore, the results of our empirical analysis provide a number of cases motivating the managers to innovate the management accounting system, posing the issue of network performance measurement as a new challenge to develop strategic alliances. In addition to the internal benefits deriving from more effective strategic settings, these managerial improvements lead to more consideration from strategic stakeholders, as demostrated by some special networkssupporting projects developed by some major Italian banking groups providing financial support only for those "agreements" with consitent business plan and management accounting processes.

Finally, in the field of public policy, our study has the following implications. On the one hand, it represents a major advancement in the study of the first cases of implementation of the new supporting program developed by Italian government; furthermore it provides criteria for discriminating the strategic alliances, the most promising form of network for economic development. On the other hand, it confirms the important role of the "trigger entities" and the "engineered process", highlighting the need for supporting with specific programmes those institutions - such as business associations - which can have a proactive role in assisting enterprises, especially SMEs, to strengthen the processes of network planning and management accounting.

\section{References}

Altheide D.L. (1996), Qualitative Media Analysis, Thousand Oaks, California, Sage.

Altheide D.L. (2004), Ethnografic Content Analysis, in Lewis-Beck M.S., Bryman A., Laio T.F., The Sage Encyclopedia of Social Science Research Methods, 3 vols, Thousand Oaks, California, Sage.

Anderson S., Dekker H. (2010), Accounting in Networks. The Transaction Cost Economics Perspective, in Hakansson H., Krauss K., Lind J., Accounting in Networks, London, Routledge.

Anderson S.W., Dekker H. (2009), Strategic cost Management in supply chains, part 1: Structural Cost Management, Accounting Horizons, 23, pp. 201-220.

Anderson S.W., Dekker H. (2009), Strategic cost Management in supply chains, part 2: Executional cost management, Accounting Horizons, 23, pp. 289-305.

Andrews K.R. (1987), The Concept of Corporate Strategy, Homewood, Irwin. 
Ansoff H.I. (1985), Corporate Strategy, London, Penguin Books.

Antonelli V. (2001), Le relazioni trasversali tra aziende. Strutture e funzionamento, Torino, Giappichelli.

Armstrong J.S. (1982), The value of formal planning for strategic decisions: review of empirical research, Strategic Management Journal, 3, 3, pp. 197-211.

Atkinson P., Coffey A. (2004), Realism and its Discontents: On the Crisis of Cultural Representation in Ethnographic Texts, in Adam B., Allen S., Theorising Culture: An interdisciplinary Critique after Postmodernism, London, UCL Press.

Azzini L. (1968), Autonomia e collaborazione tra aziende, Milano, Giuffré.

Bastia P. (1984), Gli accordi tra imprese. Fondamenti economici e strumenti informativi, Bologna, Clueb.

Bonn I., Christodoulu C. (1996), From strategic planning to strategic management, Long Range Planning, 29, 4, pp. 543-551.

Bosma N., Van Praag M., Thurik R., deWit G. (2004), The value of human and social capital investments for the business performance of startups, Small Business Economics, 23, pp. 227-236.

Boyton A.C., Zmud R.W. (1984), An assessment of CSF, Sloan Management Review, 25, 4, pp. 17-27.

Bracker J.S., Pearson J.N. (1986), Planning and financial performance of small, mature firms, Strategic Management Journal, 7, 6, pp. 503-522.

Brinckmann J., Grichnik D., Kapsa D. (2010), Should Entrepreuers plan or just storm the castle?, Journal of Business Venturing, 25, pp. 24-40.

Bryman A. (2008), Social Research Methods, Oxford, Oxford University Press.

Burns J., Scapens R.W. (2000), Conceptualising management accounting change: An institutional frame work, Management Accounting Research, 11, pp. 3-25.

Cafaggi F.(2009), Il contratto di rete, Bologna, Il Mulino.

Caglio A., Ditillo A. (2008), A review and discussion of management control in inter-firm relationships: Achievements and future directions, Accounting, Organizations and Society, 33, pp. 868-989.

Castells M. (2000), The rise of the network society, Oxford, Blackwell Publishers.

Coad A.F., Cullen J. (2006), Inter-organizational cost management: Towards and evolutionary perspective, Management Accounting Research,17, pp. 342-369.

Cooke P. (1996), The new wave of regional innovation networks: analysis, characteristics and strategy, Small Business Economics, 8, 2, pp. 159-171.

Dacin T.M., Oliver C., Roy J.P. (2007), The legitimacy of strategic alliances: An institutional perspective, Strategic Management Journal, 28, pp. 169-187.

Das T.K., Teng B.S. (1998), Between trust and control: developing confidence in partner cooperation in alliances, Academy of Management Review, Vol. 23, n. 3, 491-512.

Das T.K., Teng B.S. (1999), Managing risks in strategic alliances, Academy of Management Executive, Vol. 13, n. 4, 50-62.

Dekker H.C. (2003), Value chain analysis in interfirm relationships: a field study, Management Accounting Research, 14, 1, pp. 1-23.

Dekker H.C. (2004), Control of inter-organizational relationships: evidence on appropriation concerns and coordination requirements, Accounting, Organizations and Society, 29, 1, pp. 27-49.

Donkels R., Lambrecht J. (1995), Network and small business growth: an explanatory model, Small Business Economics, 7, pp. 273-289.

Doz Y.L., Olk P.M., Ring P.S. (2000), Formation Processes of R\&D Consortia: Which PAth to Take? Where Doeas it Lead?, Strategic Management Journal, 21, pp. 239-266. 
Dyer J.H., Singh H. (1998), The relational view: cooperative strategy and source of interorganizational competitive advantage, Academy of Management Review, 23, 4, pp. 660679.

Elfring T., Hulsink W. (2003), Networks in entrepreneurship: the case of high-technology firms, Small Business Economics, 21, pp. 409-422.

Elfring T., Hulsink W. (2003), Networks in entrepreneurship: the case of high-technology firms, Small Business Economics, 21, pp. 409-422.

Etzkovitz H. (2008), The Triple Helix, London, Routledge.

Ferrel O., Hartline M., Lucas G., Luck D. (1998), Marketing Strategy, Orlando, Dryden Press.

Garzella S. (2000), I confini d'azienda. Un approccio strategico, Milano, Giuffré.

Ghezzi A., Balocco R., Rangone A. (2010), How to Get Strategic Planning and Business Model Design Wrong: The Case of a Mobile Technology Provider, Strategic Change, 19, 213-238.

Greenwood R., Suddaby R., Hinings C.R. (2002), Theorising Change: The role of professional associations in the transformation of institutionalised fileds, Academy of Management Journal, 45, pp. 58-80.

Gulati R. (2007), Managing Network Resources. Alliances, Affiliations, and other Relational Assets, Oxford University Press.

Hakansson H., Ford D., Gadde L.E., Shenota I., Waluszewski Alexandra (2009), Business in Networks, John Wiley \& Sons Ltd, New York.

Hakansson H., Krauss K., Lind J. (2010), Accouting in Networks, London, Routledge.

Havnes P., Senneseth K. (2001), A panel study of firm growth among SMEs in networks, Small Business Economics, 16, pp. 293-302.

Hennart J.F. (1988), A transaction Costs Theory of Equity Joint Ventures, Strategic Management Journal, 9, 4, pp. 361-374.

Holm D.B., Eriksson K., Johanson J. (1999), Creating value through mutual commitment to business network relationships, Strategic Management Journal, 20, 5, pp. 467-486.

Hopwood A. (1996), Looking across rather than un and down: On the need to explore the lateral processing of information, Accounting, Organizations and Society, 29, pp. 51-72.

Houben G., Lenie K., Vanhoof K. (1999), A knowledge-based SWOT-analysis system as an instrument for strategic planning in small and medium enterprises, Decision Support System, 26, 2, pp. 125-135.

Huggins R. (2008), The Evolution of Knowledge Clusters, Economic development quarterly, 22, 4, pp. 277-289.

Huggins R. (2010), Forms of Network Resource: Knowledge Access and the Role of InterFirm Networks, International Journal of Management Review, 2010, 12, 3, pp. 335-352.

International Federation of Accountants (2006), Business Planning Guide: Practical Application for SMEs, New York, IFAC.

Jarrillo J.C. (1988), On Strategic Networks, Strategic Management Journal, 9, pp. 31-41.

Johanson M., Lundberg H. (2011), Network Strategies for Regional Growth, Palgrave MacMillan.

Kaplan R.S., Norton D.P., Rugelsjoen B. (2010), Managing Allinences with the Balanced Scorecard, Harvard Business Review, January-February 2010, pp.2-8.

Kukalis S., Jungemann M. (1995), Strategic Planning for a Joint Venture, Long Range Planning, 28, 3, pp. 46-57.

Lai A. (1991), Le aggregazioni di imprese. Caratteri istituzionali e strumenti per l'analisi economico-aziendale, Milano, FrancoAngeli. 
Langfield-Smith K., Smith D. (2003), Management control systems and trust in outsourcing relationships, Management Accounting Research, 14, 3, pp. 281-307.

Littunen, H. (2000), Networks and local environmental characteristics in the survival of new firms, Small Business Economics, Vol.15, n.1, pp.59-71.

Loizos H., Strategic Thinking or Strategic Planning, Long Range Planning, 31, 3, pp. 481487.

Macpherson A., Holt R. (2007), Knowledge, learning and small firm growth: a systematic review of the evidence, Research Policy, 36, pp. 172-192.

Mahama H. (2006), Management control systems, cooperation and performance in strategic supply relationships: a survery in the mines, Management Accounting Research, vol. 17, n. 3, pp. 315-339

Mancini D. (1999), L'azienda nella "rete di imprese”. La prospettiva del controllo relazionale, Milano, Giuffré.

Mancini D. (2010), Il sistema informativo e di controllo relazionale per il governo della rete di relazioni collaborative d'azienda, Milano, Giuffré.

Mancini D. (2011), L'azienda-rete e le decisioni di partnership: il ruolo del sistema informativo relazionale, Management Control, n. 1 2011, Milano, FrancoAngeli.

Micklethwait and Woolridge, 1997.

Miller P., Kurunmaki L., O’Leary T. (2008), Accounting, hybrids and the management of risk, Accounting, Organizations and Society, 33, 942-967.

Mintzberg H. (1994), The Rise and Fall of Strategic Planning, New York, Free Press.

Mokyr J. (2002), The Gifts of Athena: Historical Origin of the Knowledge Economy, Princeton, Princeton University Press.

Mouritsen J., Hansen A., Hansen C.O. (2001), Interorganizational controls and organizational competencies: episodes around target cost management/funzional analysis and open book accounting, Management Accounting Research, 12, 2, pp. 221-224.

Otley D., Broadbent J., Berry A. (1995), Research in management control: An overview of its development, British Journal of Management, 6, pp. 31-44.

Parker S.C. (2008), The economics of formal business networks, Journal of Business Venturing, 23, pp. 627-640.

Parkhe A. (2003), Instituitional environments, instituitional change and International alliaces, Journal of International Management, 9, pp. 305-316.

Pavit K. (2004), Changing patterns of usefulness of università research: opportunities and dangers, in Grandin K., Wormbs N., Widmalm S., The Science-Industry Nexus: History, Policy, Implications, Sagamore Beach, Watson.

Philips N., Laurence T.B., Hardy C. (2000), Inter-organizational collaboration and the dynamics of institutional fields, Journal of Management Studies, 37, pp. 23-43.

Porter M.E. (1980), Competitive Strategy: Tecniques for Analysing Industries and Competitors, New York, Free Press.

Porter M.E. (1991), Toward a dynamic theory of strategy, Strategic Management Journal, 12, pp. 95-117.

Potter J. (1996), Representing Reality: Disclosure, Rethoric and Social Construction, London, Sage.

Ricciardi A. (2003), Le reti di impresa. Vantaggi competitivi e pianificazione strategica, Milano, FrancoAngeli.

Riparbelli A. (1962), Correlazioni e interdipendenze fra organismi aziendali, Pisa, Colombo Cursi.

Rogers, M. (2002), Networks, firm size and innovation, Small Business Economics, 22, pp. 141-153. 
Rullani E. (2001), New/Net/Knowledge Economy: le molte facce del post-fordismo, Economia e Politica Industriale, 110, 135, pp. 5-32.

Sanchez R., Heene A. (1997), Reinventing strategic management: new theory and practice for competence-based competition, European Management Journal, 15, 3, pp. 303-317.

Scapens R.W., Varoutsa E. (2010), Accounting in Inter-Organisational Relationships - The Institutional Theory Perspective, in Hakansson H., Krauss K., Lind J., Accounting in Networks, London, Routledge.

Schulz A. (1962), Collected Paper I, The problem of social reality, The Hague, Martinus Nijhof.

Scott J. (1990), A matter of Record, Cambridge, Polity Press.

Seal W.B., Berry A., Cullen J. (2004), Dissembling the supply chain: Instituitionalised reflexivity and inter-firm accounting, Accounting, Organisations and Society, 29, pp. 7392.

Seal W.B., Cullen J., Dunlop A., Berry T., Ahmed M. (1999), Enacting European supply chain: a case study on the role of management accounting, Management Accounting Research, 10, 3, pp. 303-322.

Sharfman M.P., Gray B., Yan A. (1991), The context of inter-organizational collaboration in the garmet industry: An institutional perspective, Academy of management Review, 27, pp. 222-247.

Shields M.D. (1997), Research in management accounting by North Amerincans in the 1990s, Journal of Accounting Research, 9, pp. 3-61.

Strauss A. (1987), Qualitative Analysis for Social Scientist, New York, Cambridge University Press.

Tomkins C. (2001), Interdependecies, trust and information in relationship, alliances and networks, Accounting, Organizations and Society, 26, pp. 161-191.

Vitro R.A. (2005), The knowledge economy in development: perspectives for effective partnerships, Washington, D.C.

Williamson O.E. (1975), Market and Hierarchies, New York, Free Press.

Yin, R. K. (1984), Case study research: Design and methods, Newbury Park, CA, Sage Publications, Inc.

Yin, R. K. (Ed.). (2004), The case study anthology, Thousand Oaks, CA, Sage Publications Inc.

\begin{tabular}{|c|c|c|c|c|c|c|c|c|}
\hline \multirow[b]{2}{*}{$\begin{array}{l}\text { Network } \\
\text { Agreements }\end{array}$} & \multicolumn{2}{|c|}{$\begin{array}{c}\text { Strategic } \\
\text { context }\end{array}$} & \multicolumn{2}{|c|}{$\begin{array}{c}\text { Strategic } \\
\text { analysis }\end{array}$} & \multicolumn{2}{|c|}{$\begin{array}{c}\text { Strategic } \\
\text { goal-setting }\end{array}$} & \multicolumn{2}{|c|}{$\begin{array}{l}\text { Action plan } \\
\text { Focus }\end{array}$} \\
\hline & $\begin{array}{l}\text { Trigger } \\
\text { entity }\end{array}$ & $\begin{array}{l}\text { Engin. } \\
\text { process }\end{array}$ & External & Internal & Goals & Obj's & $\begin{array}{l}\text { Process- } \\
\text { driven }\end{array}$ & $\begin{array}{l}\text { Market- } \\
\text { driven }\end{array}$ \\
\hline 1 & & & & $\mathrm{x}$ & $\mathrm{x}$ & & $x$ & \\
\hline 2 & & & & & $\mathrm{x}$ & & $\mathrm{X}$ & \\
\hline 3 & $\mathrm{x}$ & $\mathrm{x}$ & & $\mathrm{x}$ & & $\mathrm{X}$ & $\mathrm{x}$ & \\
\hline 4 & & & & $x$ & $\mathrm{x}$ & & $\mathrm{X}$ & \\
\hline 5 & & & $\mathrm{x}$ & & & $\mathrm{x}$ & & $\mathrm{x}$ \\
\hline 6 & $\mathrm{x}$ & $\mathrm{x}$ & $\mathrm{X}$ & $\mathrm{x}$ & $\mathrm{x}$ & & $\mathrm{X}$ & $\mathrm{X}$ \\
\hline 7 & $\mathrm{X}$ & & & & $x$ & & & $x$ \\
\hline 8 & & & & $\mathrm{x}$ & $\mathrm{x}$ & & $\mathrm{x}$ & \\
\hline 9 & & $\mathrm{x}$ & $\mathrm{x}$ & & $\mathrm{x}$ & & & $\mathrm{x}$ \\
\hline 10 & & & & $\mathrm{x}$ & $\mathrm{x}$ & & $\mathrm{x}$ & \\
\hline 11 & & & & & $\mathrm{X}$ & & $\mathrm{x}$ & \\
\hline 12 & $\mathrm{x}$ & $x$ & & $x$ & $\mathrm{x}$ & & $\mathrm{x}$ & $\mathrm{x}$ \\
\hline 13 & & $x$ & & $\mathrm{x}$ & $\mathrm{x}$ & & $\mathrm{x}$ & \\
\hline
\end{tabular}


Business planning and management accounting in strategic networks

\begin{tabular}{|c|c|c|c|c|c|c|c|c|}
\hline 14 & & & $\mathrm{X}$ & & $\mathrm{X}$ & & & $X$ \\
\hline 15 & $X$ & & & & $\mathrm{X}$ & & $X$ & \\
\hline 16 & & & & $X$ & $\mathrm{X}$ & & $\mathrm{X}$ & \\
\hline 17 & & & & & $\mathrm{X}$ & & $\mathrm{X}$ & \\
\hline 18 & & & & $X$ & $\mathrm{X}$ & & $\mathrm{X}$ & \\
\hline 19 & & & & & $\mathrm{X}$ & & $\mathrm{X}$ & \\
\hline 20 & & & & $X$ & & $\mathrm{X}$ & $\mathrm{X}$ & \\
\hline 21 & & & & $X$ & $X$ & & $\mathrm{X}$ & $X$ \\
\hline 22 & & $\mathrm{X}$ & & $X$ & $\mathrm{X}$ & & $\mathrm{X}$ & $\mathrm{X}$ \\
\hline 23 & $\mathrm{X}$ & $\mathrm{X}$ & $\mathrm{X}$ & $\mathrm{X}$ & $\mathrm{X}$ & $\mathrm{X}$ & $\mathrm{X}$ & \\
\hline 24 & & & & $\mathrm{X}$ & $\mathrm{X}$ & & $\mathrm{X}$ & \\
\hline 25 & & & & $\mathrm{X}$ & & $X$ & $\mathrm{X}$ & \\
\hline 26 & & & & $X$ & $\mathrm{X}$ & & $\mathrm{X}$ & $\mathrm{X}$ \\
\hline 27 & & & $\mathrm{X}$ & & & $X$ & $X$ & \\
\hline 28 & & & & $\mathrm{X}$ & $\mathrm{X}$ & & $\mathrm{X}$ & \\
\hline 29 & $X$ & & & & & $X$ & & \\
\hline 30 & $\mathrm{X}$ & $\mathrm{X}$ & $\mathrm{X}$ & & $\mathrm{X}$ & & $\mathrm{X}$ & \\
\hline 31 & & & $X$ & & & $X$ & $\mathrm{X}$ & $\mathrm{X}$ \\
\hline 32 & & & & $X$ & $\mathrm{X}$ & & $X$ & \\
\hline 33 & $X$ & $\mathrm{X}$ & & $X$ & & $X$ & $\mathrm{X}$ & $\mathrm{X}$ \\
\hline 34 & & & & $X$ & $\mathrm{X}$ & & $\mathrm{X}$ & \\
\hline 35 & & & & & $\mathrm{X}$ & & $\mathrm{X}$ & \\
\hline 36 & $X$ & $X$ & & $X$ & $X$ & & $X$ & \\
\hline 37 & & & & & $\mathrm{X}$ & & $\mathrm{X}$ & \\
\hline 38 & & & & & & & $\mathrm{X}$ & \\
\hline 39 & $\mathrm{X}$ & $\mathrm{X}$ & & $\mathrm{X}$ & $\mathrm{X}$ & & $\mathrm{X}$ & \\
\hline 40 & & $X$ & & $\mathrm{X}$ & $\mathrm{X}$ & & $X$ & \\
\hline 41 & & $\mathrm{X}$ & & $X$ & $\mathrm{X}$ & & $\mathrm{X}$ & \\
\hline 42 & & & & & & & $\mathrm{X}$ & \\
\hline 43 & & $\mathrm{X}$ & $\mathrm{X}$ & $\mathrm{X}$ & $\mathrm{X}$ & $\mathrm{X}$ & $\mathrm{X}$ & \\
\hline 44 & & & & $X$ & $\mathrm{X}$ & $\mathrm{X}$ & $\mathrm{X}$ & \\
\hline 45 & & & & & & & $\mathrm{X}$ & \\
\hline 46 & $\mathrm{X}$ & $X$ & $X$ & & $\mathrm{X}$ & $\mathrm{X}$ & & $\mathrm{X}$ \\
\hline 47 & $\mathrm{X}$ & $\mathrm{X}$ & & $\mathrm{X}$ & $\mathrm{X}$ & $\mathrm{X}$ & $\mathrm{X}$ & $\mathrm{X}$ \\
\hline 48 & & & & & $\mathrm{X}$ & & $\mathrm{X}$ & \\
\hline 49 & & & & & & & & $\mathrm{X}$ \\
\hline 50 & & & & $\mathrm{X}$ & $\mathrm{X}$ & & $\mathrm{X}$ & \\
\hline$\%$ & $26 \%$ & $32 \%$ & $20 \%$ & $58 \%$ & $76 \%$ & $26 \%$ & $86 \%$ & $28 \%$ \\
\hline
\end{tabular}

Appendix B - Strategic performance measurement and management accounting

Strategic Measur. Management Financial Predominant Commitment Accounting perspective Role

\begin{tabular}{|c|c|c|c|c|c|c|c|}
\hline & & & & & & & \\
\hline $\begin{array}{c}\text { Network } \\
\text { Agreement }\end{array}$ & General & Specific & $\begin{array}{l}\text { Planning/ } \\
\text { Control }\end{array}$ & $\begin{array}{l}\text { Costing } \\
\text { Pricing }\end{array}$ & Budgeting & Reporting & \\
\hline 1 & $\mathrm{X}$ & & & & & $\mathrm{X}$ & Traditional/Formal \\
\hline 2 & $\mathrm{x}$ & & & & $\mathrm{x}$ & $\mathrm{x}$ & Traditional/Formal \\
\hline 3 & $\mathrm{X}$ & & $\mathrm{x}$ & & & & - \\
\hline 4 & $\mathrm{x}$ & & $\mathrm{x}$ & $\mathrm{x}$ & & $\mathrm{x}$ & Traditional/Manag. \\
\hline 5 & $\mathrm{X}$ & & & $\mathrm{X}$ & & $\mathrm{X}$ & Traditional/Formal \\
\hline 6 & & $\mathrm{X}$ & $\mathrm{x}$ & $\mathrm{X}$ & & $\mathrm{X}$ & Innovative/Manag. \\
\hline 7 & & $\mathrm{X}$ & & & & $\mathrm{X}$ & Traditional/Formal \\
\hline 8 & $\mathrm{X}$ & & & & $\mathrm{X}$ & $\mathrm{X}$ & Traditional/Formal \\
\hline 9 & & $\mathrm{X}$ & $\mathrm{x}$ & & $\mathrm{X}$ & $\mathrm{X}$ & Traditional/Manag. \\
\hline 10 & $\mathrm{X}$ & & & & $\mathrm{X}$ & $\mathrm{X}$ & Traditional/Formal \\
\hline 11 & $\mathrm{X}$ & & & & $\mathrm{X}$ & $\mathrm{X}$ & Traditional/Formal \\
\hline 12 & $\mathrm{X}$ & & & & $\mathrm{X}$ & $\mathrm{X}$ & Traditional/Formal \\
\hline 13 & & & $\mathrm{x}$ & & & & Traditional/Manag. \\
\hline
\end{tabular}




\begin{tabular}{|c|c|c|c|c|c|c|c|}
\hline 14 & & $\mathrm{X}$ & $\mathrm{X}$ & & $\mathrm{X}$ & $\mathrm{X}$ & Traditional/Manag. \\
\hline 15 & X & & & & & & - \\
\hline 16 & & $\mathrm{X}$ & $\mathrm{X}$ & & $\mathrm{x}$ & $\mathrm{x}$ & Traditional/Formal \\
\hline 17 & $\mathrm{X}$ & & & & & & - \\
\hline 18 & $\mathrm{X}$ & & & & $\mathrm{X}$ & $\mathrm{X}$ & Traditional/Formal \\
\hline 19 & $\mathrm{X}$ & & & & $\mathrm{X}$ & $\mathrm{X}$ & Traditional/Formal \\
\hline 20 & & $\mathrm{X}$ & & & & & - \\
\hline 21 & $\mathrm{X}$ & & $\mathrm{X}$ & & $\mathrm{X}$ & $\mathrm{X}$ & Innovative/Manag. \\
\hline 22 & & $\mathrm{X}$ & $\mathrm{X}$ & $\mathrm{X}$ & $\mathrm{X}$ & $\mathrm{X}$ & Innovative/Manag. \\
\hline 23 & $\mathrm{X}$ & & $\mathrm{X}$ & $\mathrm{X}$ & & & Innovative/Manag. \\
\hline 24 & $\mathrm{X}$ & & & & $\mathrm{x}$ & $\mathrm{X}$ & Traditional/Formal \\
\hline 25 & $\mathrm{X}$ & & & & $\mathrm{X}$ & $\mathrm{X}$ & Traditional/Formal \\
\hline 26 & $\mathrm{X}$ & & & & $\mathrm{X}$ & $\mathrm{X}$ & Traditional/Formal \\
\hline 27 & $\mathrm{X}$ & & & & $\mathrm{X}$ & $\mathrm{X}$ & Traditional/Formal \\
\hline 28 & & $\mathrm{X}$ & $\mathrm{X}$ & $\mathrm{X}$ & & & Innovative/Manag. \\
\hline 29 & & $\mathrm{X}$ & $\mathrm{X}$ & & & $\mathrm{x}$ & Traditional/Manag. \\
\hline 30 & $\mathrm{X}$ & & $\mathrm{X}$ & & $\mathrm{X}$ & $\mathrm{X}$ & Traditional/Formal \\
\hline 31 & & $\mathrm{X}$ & $\mathrm{X}$ & $\mathrm{X}$ & & & Innovative/Manag. \\
\hline 32 & & $\mathrm{X}$ & $\mathrm{X}$ & & $\mathrm{X}$ & $\mathrm{X}$ & Traditional/Formal \\
\hline 33 & & $\mathrm{X}$ & $\mathrm{X}$ & & $\mathrm{X}$ & $\mathrm{X}$ & Traditional/Formal \\
\hline 34 & & $\mathrm{X}$ & $\mathrm{X}$ & & $\mathrm{X}$ & $\mathrm{X}$ & Traditional/Formal \\
\hline 35 & $\mathrm{X}$ & & & & & $\mathrm{X}$ & Traditional/Formal \\
\hline 36 & & $\mathrm{X}$ & $\mathrm{X}$ & $\mathrm{X}$ & & & Innovative/Manag. \\
\hline 37 & $\mathrm{X}$ & & & $\mathrm{X}$ & & & - \\
\hline 38 & & $\mathrm{X}$ & $\mathrm{X}$ & & & & Innovative/Manag. \\
\hline 39 & & $\mathrm{X}$ & $\mathrm{X}$ & & $\mathrm{x}$ & $\mathrm{X}$ & Traditional/Manag. \\
\hline 40 & & $\mathrm{X}$ & $\mathrm{X}$ & $\mathrm{X}$ & & & Innovative/Manag. \\
\hline 41 & & $\mathrm{X}$ & $\mathrm{X}$ & $\mathrm{X}$ & & & Traditional./Manag. \\
\hline 42 & & $\mathrm{X}$ & & $\mathrm{X}$ & & & Traditional/Manag. \\
\hline 43 & & $\mathrm{X}$ & $\mathrm{X}$ & & & $\mathrm{X}$ & Innovative/Manag. \\
\hline 44 & $\mathrm{X}$ & & & & $\mathrm{x}$ & $\mathrm{X}$ & Innovative/Manag. \\
\hline 45 & $\mathrm{X}$ & & & & & & - \\
\hline 46 & $\mathrm{X}$ & & $\mathrm{X}$ & & $\mathrm{x}$ & $\mathrm{X}$ & Traditional/Manag. \\
\hline 47 & & $\mathrm{X}$ & $\mathrm{X}$ & $\mathrm{X}$ & $\mathrm{x}$ & $\mathrm{X}$ & Innovative/Manag. \\
\hline 48 & & $\mathrm{X}$ & & & & & - \\
\hline 49 & & $\mathrm{X}$ & $\mathrm{X}$ & & $\mathrm{x}$ & $\mathrm{X}$ & Traditional/Formal \\
\hline 50 & $\mathrm{X}$ & & & & $\mathrm{X}$ & $\mathrm{X}$ & Traditional/Formal \\
\hline$\%$ & $52 \%$ & $48 \%$ & $52 \%$ & $26 \%$ & $54 \%$ & $68 \%$ & - \\
\hline
\end{tabular}

